УДК 616.37-002.1-085.874

DOI 10.11603/2414-4533.2018.3.9446

(сС. М. ЧУКЛІН, С. С.ЧУКЛІН, Г. В. ШЕРШЕНЬ, П. М. ПОПИК

Львівська обласна клінічна лікарня

\title{
Особливості харчової підтримки у хворих на гострий панкреатит (огляд літератури)
}

\begin{abstract}
Харчування є істотною частиною у лікування хворих на гострий панкреатит. Очевидно, у легких та середньої тяжкості випадках нема необхідності застосовувати штучні методи харчування, навпаки, рекомендовано розпочати пероральне приймання їжі. Проте вид харчування і терміни його початку ще обговорюються. Якщо ж стан пацієнта тяжкий, доцільно розпочати ентеральне харчування, яке зменшує ризик приєднання інфекції, тривалість перебування в стаціонарі, смертність. Парентеральне харчування призначають лише, якщо ентеральне не можливе. Однак залишаються дискусійними, який вид харчування застосовувати краще, ефективніший шлях, а також правильний алгоритм дій при цьому. Огляд літератури присвячений розгляду усіх цих питань. Підсумовуючи, можна стверджувати про необхідність проведення більшої кількості досліджень із питання харчування у пацієнтів із гострим панкреатитом.
\end{abstract}

Ключові слова: гострий панкреатит; лікування; харчова підтримка.

Кількість хворих на гострий панкреатит (ГП) зростає у всьому світі $[1,2]$. У більшості пацієнтів ГП перебігає у легкій формі, проте у 15-20 \% хворих виникає некротичний панкреатит, летальність при якому сягає 10-15 \% [3]. У разі інфікування некрозу підшлункової залози, стійкої органної дисфункції або обидвох смертність зростає до $30 \%[4]$.

Незважаючи на відсутність спеціальної терапії у лікуванні хворих на ГП, останні досягнення, які використовують неспецифічні ранні методи лікування, привели до покращення результатів. Дані результати отримано з рандомізованих контрольованих досліджень (РКД) із застосуванням регідратації, аналгезії, профілактичних антибіотиків та обмеження ендоскопічної ретроградної холангіопанкреатографії в пацієнтів із супутнім гострим холангітом [5. 6]. Проте найпомітніше і послідовне покращення результатів пацієнтів за останнє десятиріччя було відзначено у дослідженнях, що вивчали використання штучного харчування, як ентерального, так і парентерального, у пацієнтів із ГП.

ГП пов'язаний із системними та метаболічними розладами через виділення гідролітичних ферментів, токсинів і цитокінів і може призвести до недостатності декількох систем організму. Це може сприяти гіперметаболізму та негативному балансу азоту з негативним балансом енергії $[7,8]$. Крім того, тяжкий панкреатит може бути причиною гіперглікемії і викликати діабет [9, 10]. Інтервенційні втручання (хірургічні, ендоскопічні та радіологічні), виконані частині пацієнтів [11], також ускладнюють харчову підтримку у хворих на ГП.

В статті розглянуто наявні докази щодо нутриційної підтримки у хворих на ГП залежно від тяжкості патологічного процесу. Обговорюються шляхи, терміни та тип харчової підтримки.

\section{Ентеральне і парентеральне харчування}

Оптимальна підтримка харчування при ГП була предметом дебатів протягом десятиліть. Важливість забезпечення штучного харчування у пацієнтів із ГП є визнаною з 1970-х років. Парентеральне харчування (ПХ) розглядалося як стандарт дієтотерапії протягом майже 4 десятиліть і базувалося на концепції “спокою підшлункової залози”. Вона, у свою чергу, ґрунтується на запобіганні стимуляції екзокринної функції та вивільнення протеолітичних ферментів, які посилюють “аутоліз”. Тривалий період вважали, що харчування, яке вводиться проксимальніше зв'язки Treitz', стимулюватиме підшлункову залозу і тим самим посилить тяжкість ГП [12]. Концепція “спокою підшлункової залози" передбачає, що ентеральне харчування (EX), що надходить у будь-яку частину верхніх відділів травного каналу, крім середнього і дистального відділу порожньої кишки (40 см і більше від зв'язки Treitz' у дистальньому напрямку), стимулює секрецію підшлункової залози. Основними принципами “спокою підшлункової залози” $є$ те, що пероральне харчування необхідно розпочинати лише тоді, коли зникають симптоми ГП і нормалізуються показники ферментів підшлункової залози в крові. Крім того, стимуляція підшлункової залози мінімізується за рахунок використання елементарного хімічного складу та поетапного введення перорального харчування (прозора рідина, м'яка їжа та тверда їжа). 3 цієї причини ПХ вважалося ідеальним для адекватної підтримки харчування без стимуляції підшлункової залози. Проте при ГП відсутні рандомізовані досліджен- 
ня, в яких порівнюють ПХ лише з внутрішньовенними рідинами. Водночас ПХ супроводжується численними ускладненнями, такими як інфекції, пов'язані із центральним венозним катетером, та метаболічні розлади [13].

Проте зібрані докази руйнують ці загальноприйняті вірування. Показано, що пацієнти з ГП мають значно нижчий рівень секреції ферментів порівняно зі здоровими особами, і вона зворотно пропорційна тяжкості ГП [14]. Окрім того, коли пацієнтів із ГП легкого та середнього ступенів тяжкості порівняли із пацієнтами з важким ГП, було виявлено зниження секреції трипсину (у 6 разів), амілази (у 22 рази) та ліпази (у 42 рази) у другій групі [14]. Інше дослідження показало, що ознаки екзокринної недостатності підшлункової залози (визначалася за рівнем панкреатичної еластази-1 у калі) спостерігалися у 86 \% пацієнтів, що проходили лікування після нападу ГП [15]. Знову ж таки, виразність екзокринної недостатності підшлункової залози співвідноситься з тяжкістю захворювання. Ці дані дозволяють припустити, що при ГП пошкоджені ацинарні клітини не можуть повною мірою реагувати на фізіологічну стимуляцію секреції [16].

Дисфункція кишкового бар’єра спостерігається приблизно в 60 \% пацієнтів з ГП [17]. Ентеральне харчування має такі імуномодулюючі ефекти, як збереження цілісності слизової оболонки кишок, стимулює перистальтику - тим самим зменшуючи надмірний ріст бактерій, і може збільшити спланхнічний кровоплин [18]. Як результат, можна перешкоджати бактеріальній транслокації 3 кишок [19]. Тому вважають, що ЕX може знизити ризик інфікування некрозу підшлункової залози та смертності [20], хоча не було опубліковано рандомізованого дослідження, щоб підтвердити цю гіпотезу.

31996 р. 12 РКД [21-32], які включали 555 хворих на ГП, порівнювали ЕХ та ПХ. 3 цими 12 випробуваннями було проведено 8 мета-аналізів. Три останніх мета-аналізи показали, що EX значно знижує інфікування, органну недостатність та смертність у пацієнтів з ГП порівняно з ПХ [3335]. Тому сучасні рекомендації віддають перевагу ентеральному харчуванню над парентеральним [36-39]. Проте ці рандомізовані дослідження мають кілька обмежень, які слід враховувати.

По-перше, критерії включення значно варіювалися між випробуваннями. Використовувались різні системи прогнозування з пороговими значеннями. Деякі дослідження включали пацієнтів 3 легким ГП, які не потребували харчової підтримки. Незважаючи на великі дослідження, системні шкали досягають лише скромної точності у прогнозуванні ускладнень при ГП [40]. Це призводить до включення пацієнта, визначеного як прогнозований тяжкий, але в якого кінцево розвивається легкий панкреатит. Це відоме обмеження інтервенцій на ранніх стадіях захворювання при ГП. На жаль, на сьогодні не існує точніших інструментів, ніж існуючі системи. У кількох випробуваннях також використовували інші критерії включення, ніж шкали прогнозування, такі як неможливість перорального приймання їжі після 48 год [22] або через 96 год [26], або контрастнопосилене комп'ютерне томографічне свідчення про некроз підшлункової залози [25], або індекс тяжкості при комп'ютерній томографії більше 6 [31]. Ці різні критерії включення зумовили гетерогенне включення пацієнтів із ГП. Це також відображається в зміні частоти ускладнень між випробуваннями. Найвищий рівень смертності становив $43 \%$ порівняно з $0 \%$ [30, 24]. Швидкість органної недостатності коливалася від 81 до 8 \% [30, 21]. При інтерпретації результатів мета-аналізу з включенням відносно легких та тяжких пацієнтів ці відмінності слід враховувати: випробування з високими показниками ускладнень дуже впливають на результат мета-аналізу.

По-друге, більшість досліджень були спрямовані на запобігання таких ускладнень, як інфекції. Ускладнення та інфекції можуть розвиватися на початку хвороби. Тому рекрутування пацієнтів на ранніх стадіях захворювання, перш ніж виникли ускладнення, $є$ вирішальним [11, 41]. Це часове вікно мале, і клінічне погіршення може виникнути несподівано. Для ефективної ранньої профілактики ускладнень пацієнти теоретично повинні бути ідентифіковані після госпіталізації або протягом перших 24-48 год після надходження в лікарню. Час включення, рандомізації та початку втручання варіювався між випробуваннями відразу після госпіталізації [23] до 96 год після надходження [26]. Дуже ймовірно, що через 96 год після госпіталізації профілактичні втручання більше не будуть ефективними.

По-третє, існує велика різниця в розмірі вибірки між дослідженнями. Найчастіше було підтверджено, що невеликі дослідження, як правило, повідомляють про переваги лікування більше, ніж у великих дослідженнях [42]. Це може бути результатом поєднання нижчої методологічної якості, публікації та інших упереджень щодо звітності, але може також відображати клінічну неоднорідність, якщо невеликі випробування були обережніші при відборі пацієнтів та здійсненні експериментального втручання [42]. Проте, коли ці неве- 
ликі випробування об’єднуються в мета-аналізи, можна виявити значні відмінності. Дійсність цих вірогідних результатів піддається сумніву.

По-четверте, багато досліджень було зроблено до того, як гіперглікемія була визнана фактором ризику інфікування. Поширеність гіперглікемії у пацієнтів, які отримують спеціалізовану харчову підтримку, вища, і повідомляється про 30 \% пацієнтів, які отримують ентеральне харчування, i більше половини хворих, які отримують парентеральне [43]. У свою чергу, гіперглікемія збільшує ризик інфекційних ускладнень та смертності при парентеральному харчуванні [44]. Глікемічний контроль покращує клінічний результат і може зменшити кількість і перебіг ускладнень [45, 46].

Нарешті, у деяких дослідженнях не завжди звертали увагу на калорійність. Це може призвести до погіршення клінічного результату. Тільки два дослідження з ентерального харчування враховували калорійність [22, 32]. Вони продемонстрували значне зниження кількості білка та споживання калорій. У кількох дослідженнях кількість білка або споживання калорій були подібними між групами [21, 30, 31], а в одному - про калорійність не повідомлялося [27].

Хоча вважається, що результат є гіршим, якщо не досягнуто калорійності, нещодавнє РКД у критично хворих пацієнтів показало, що смертність була подібною у хворих із недоїданням порівняно зі стандартним ЕX [47].

Незважаючи на зазначені обмеження, рекомендується ентеральне харчування у пацієнтів 3 ГП, які потребують харчової підтримки. Парентеральне харчування призначається лише тоді, коли ентеральне не переноситься і необхідна нутриційна підтримка $[48,49]$. Проте у повсякденній практиці, складно спрогнозувати, чи буде ЕX переноситися пацієнтами з ГП, особливо при різних варіантах перебігу.

\section{Час ентеральної підтримки}

Час початку ентеральної підтримки має вирішальне значення для вирішення проблем, пов'язаних із проникністю кишок та бактеріальною транслокацією. Мета-аналіз, проведений Petrov M. зі співавт. [50], який грунтується на 11 РКД (451 пацієнт), виявив, що переваги ЕX перед ПХ з точки зору зниження поліорганної дисфункції, панкреатичних інфекційних ускладнень та смертності були статистично значущими, якщо $\mathrm{EX}$ було розпочато протягом перших 48 годин від госпіталізації. Після цього часу суттєвих відмінностей не спостерігалося порівняно з ПХ. Переваги початку EX при ГП до 48 год від госпіталізації також спостерігались в інших дослідженнях
[51, 52] та мета-аналізі [53]. У мета-аналізі, проведеному на 8 РКД (165 пацієнтів), Bakker O. зі співавт. [54] показали, що початок ЕХ протягом 24 год після надходження до лікарні, порівняно 3 початком після 24 год, був пов'язаний з меншими ускладненнями.

У рекомендаціях Італійської асоціації з вивчення підшлункової залози (AISP) [55] вказало, що ЕX слід починати протягом 24-48 год після госпіталізації (доказ рівня 1, рекомендація класу А).

Нутриційна підтримка при легкому і середньої тяжкості ГП

Довгий час вважали, що пероральне харчування посилює напад ГП або спричиняє рецидив болю [56]. Рецидив болю після перорального приймання асоціюється з тривалішим перебуванням у лікарні та збільшенням витрат [57]. Проте систематичний огляд [58] показав, що лише близько 20 \% пацієнтів відчувають рецидив болю під час легкого ГП. У 80 \% цих пацієнтів рецидив болю відбувся протягом перших 48 год після початку перорального приймання їжі [58]. Рандомізоване дослідження у пацієнтів з прогнозованим легким панкреатитом, яке порівнювало ентеральне харчування, розпочате при госпіталізації, з голодуванням, виявило суттєве зменшення болю, потребу в опіатах та ризику непереносимості їжі для перорального харчування на користь раннього ентерального харчування [59]. На жаль, ці відмінності не привели до скорочення перебування в лікарні. Ще одне рандомізоване дослідження включало 60 пацієнтів з прогнозованим легким ГП, які були рандомізовані на дві групи: пероральне годування після купірування болю і негайно розпочате пероральне годування. Тривалість перебування в лікарні була коротша, коли пероральне годування було розпочато негайно $(\mathrm{p}=0.047)$. Не було ніяких відмінностей у відновленні болю та рівнях амілази в сироватці крові [60]. Також не було виявлено значних відмінностей у дослідженні, яке порівнювало пероральне харчування з урахуванням початку перорального харчування після нормалізації рівня ліпази у сироватці крові [61].

Тому вважається, що при легкому та середньої тяжкості ГП пацієнти можуть споживати їжу через рот, коли зменшуються болі в животі, нудота та блювота, особливо коли апетит повертається [38, 62]. Кілька досліджень порівнювали різні види початкового харчування (наприклад, м'яка їжа, рідка їжа, тверда їжа) у пацієнтів з легким ГП [63, $54,65]$. Жодне з досліджень не показало більшого повторення болю після певної дієти. Традиційно пацієнти починають харчуватися поступово, починаючи з чистих рідин, протягом перших 24 год, 
коли біль у животі відсутній, і панкреатичні ферменти зменшуються, а потім вживають м’яку їжу 3 низьким вмістом жиру, а при переносимості через 24 год - тверду їжу з низьким вмістом жиру [66]. Проте рандомізоване дослідження, яке порівнювало пероральний початок харчування м'якою їжею з чистими рідинами при легкому ГП, не виявило істотної різниці в клінічному результаті в обох групах. Більш того, початок $з$ твердої їжі пов'язаний із суттєвим зменшенням тривалості перебування в стаціонарі (середній ліжко-день 5 проти 8, коли починали з чистих рідин, $\mathrm{p}<0,001$ ) [63]. Пізніше рандомізоване відкрите дослідження [67] показало, що не було відмінностей при порівнянні поступово збільшеної дієти з негайно повною калорійною дієтою. Мета-аналіз показав зменшення тривалості перебування в лікарні при нерідкій дієті [68]. Нещодавні дослідження фактично показали, що переїдання з повноцінною калорійною дієтою з низьким вмістом жиру є безпечним та добре переноситься, коли перистальтика присутня у всіх пацієнтів з легким ГП [67]. Два останніх дослідження показали, що у пацієнтів 3 ГП (легким або середньої тяжкості) стратегія із пероральним харчуванням з рідкою їжеюю з низьким вмістом жиру і початком після того, як вони суб'єктивно відчували голод порівняно зі стратегією рутинного перорального початку харчування (відсутність дискомфорту у животі, зменшення рівня амілази або ліпази в сироватці крові, нормальна перистальтика кишок), було безпечною, доцільною та значно скоротила тривалість перебування в лікарні $[69,70]$.

Голодування при постійному болю у животі при легкому ГП не повинно перевищувати п’яти діб. У такому випадку потрібне зондове харчування [38, 62].

3 огляду на ці результати, у пацієнтів з легким або середньої тяжкості ГП рекомендується почати пероральне харчування з нерідкою їжею, коли біль у животі зменшується, вони є гемодинамічно стабільними, і пацієнт вимагає перорального харчування.

\section{Підтримка харчування при тяжкому ГП}

При тяжкому ГП зменшення скоротливості тонкої кишки сприяє надмірному бактеріальному росту, знижує спланхнічний кровоплин, збільшує проникність кишок [71]. Ці патологічні процеси можуть посилити системну запальну відповідь. Поточні дані підтверджують, що дуже ранній початок ентерального харчування при тяжкому ГП має трофічний ефект на цілісність стінки кишок та може зменшити запальну відповідь [71]. Ця гіпотеза була підтверджена кількома дослідження- ми [51, 52], включно кілька звичайних мета-аналізів [50, 53, 72] та нещодавній мета-аналіз індивідуальних даних пацієнтів [54].

У багатьох міжнародних рекомендаціях [38, $55,62]$ зазначено, що харчова підтримка при тяжкому ГП повинна бути надана шляхом ентерального харчування (клас рекомендації А). EX необхідно надати перевагу перед ПХ, навіть якщо присутні ускладнення, зокрема, нориці, асцит і псевдокісти (клас рекомендації С) [38]. ЕХ є доцільним i рекомендується шляхом інтраопераційної єюностомії навіть після операції з приводу панкреатиту (клас рекомендації С) [39]. Ентеральне зондове харчування забезпечує безпечну харчову підтримку при ГП, навіть у випадках виникнення шлункової обструкції [73]. У цьому випадку кінчик зонда повинен розташовується дистальніше перешкоди (клас рекомендації С) [39]. Єдиним фактичним протипоказанням до EX є тривала паралітична непрохідність. Проте навіть у цьому випадку ESPEN (European Society for Parenteral and Enteral Nutrition - Європейське товариство з парентерального та ентерального харчування) ре-комендує поєднувати ПХ із невеликим вмістом елементарної або імунопосилюючої дієти (10-30 мл/год), яку безперервно вводять у порожню кишку [74]. Що стосується часу підтримки, перевагу треба надавати безперервній інфузії перед болюсним введенням (клас рекомендації В) [39].

Проте жодне з рандомізованих досліджень, в основному, не зосереджувалося на термінах ентерального годування. Нещодавно було опубліковано перше багатоцентрове рандомізоване дослідження, і якому спеціально досліджувалися терміни ентерального харчування у пацієнтів із прогнозованим тяжким ГП (PYTHON trial) [75]. Пацієнтів з прогнозованим тяжким ГП рандомізували, щоб отримати або раннє ентеральне харчування через назоєюнальний зонд (протягом 24 год після госпіталізації) або в режимі “нічого перорально” протягом 72 год, після чого проводилося пероральне харчування. Якщо перорального приймання було недостатньо, встановлювали харчовий зонд та розпочинали ентеральне харчування (стратегія за вимогою - on-demand strategy). Всього було включено 208 хворих із прогнозованим важким ГП. Визначали інфекційні ускладнення або смерть протягом 6 місяців після рандомізації. Інфекційні ускладнення виникли у 25 \% пацієнтів у ранній групі, порівняно з 26 \% у групі за вимогою $(\mathrm{p}=0,87)$. Смертність становила $11 \%$ у ранній групі та 7 \% у групі за вимогою $(\mathrm{p}=0,33)$. За допомогою пероральної дієти та стратегії харчування за вимогою тільки приблизно третина па- 
цієнтів потребували назоєюнального зондового харчування.

Це дослідження не показало гіпотетичну перевагу раннього назоентерального харчування у пацієнтів з ГП, які мали високий ризик ускладнень. Спостереження про те, що клінічні результати раннього зондового харчування були подібні до дієти, розпочатої через 72 год, із додатковим зондовим харчуванням, якщо це було потрібно, ставить під сумнів концепцію збереження слизової оболонки кишок при ранньому ентеральному харчуванні при ГП. Якщо зондове годування обмежується пацієнтами, які не переносять або не мають достатнього споживання з допомогою пероральної дієти, це може призвести до значного уникнення дискомфорту та витрат [76].

Досягнення калорійних цілей при ентеральному харчуванні може бути складним для критично хворих пацієнтів. Часто калорійність не досягається лише шляхом ентерального харчування [77]. Крім того, підгодовування пов'язане з інфекцією [78], збільшення тривалості механічної вентиляції [79, 80], а також смертністю [81]. Здається логічним почати раннє парентеральне харчування, щоб доповнити недостатнє ентеральне годування протягом першого тижня після госпіталізації у тяжкохворих пацієнтів з ризиком мальнутриції. На відміну від цієї гіпотези, рандомізоване дослідження [49] та мета-аналіз [48] показали, що раннє парентеральне харчування було гіршим за стратегію, яка не застосовує парентеральне харчування до 8-го дня. Пізнє парентеральне харчування було пов'язане зі статистично значущим меншим рівнем інфекцій, посиленням відновлення і нижчими витратами. 3 огляду на ці результати 3 парентеральним харчуванням слід утримуватися до 7-го дня, якщо не досягнуто цілей калорійності.

Майбутні дослідження потребують визначення оптимального часу початку парентерального харчування у пацієнтів з тяжким ГП.

\section{Назоєюнальне або назогастральне году- вання?}

Дослідження з ентерального харчування при ГП зосереджені, головним чином, на харчуванні через назоєюнальний зонд для оптимальної доставки їжі [33]. Назоєюнальні харчові зонди мають певні переваги над назогастральними. Наприклад, коли розміщуються за зв'язкою Treitz', зменшується ризик міграції зонда в шлунок і запобігається рефлюкс ентерального харчування в шлунок [82]. Дослідження показали, що єюнальне годування (навіть елементарним харчуванням) все ще стимулює підшлункову залозу через гормональні шляхи, через кров і холінергічні енте- ропанкреатичні рефлекси [82, 83]. Лише при ентеральному харчуванні в серединно-дистальному відділі порожньої кишки стимуляція підшлункової залози відсутня [84].

Назогастральний харчовий зонд $є$ альтернативою, яка може з часом викликати подібну стимуляцію підшлункової залози, але це проста процедура. У трьох дослідженнях порівнювалися назоєюнальне з назогастральним харчуванням у пацієнтів з важким ГП. РКД Singh N. зі співавт. [85] було розроблено як дослідження для підтвердження не найгіршого результату лікування та включало загалом 78 пацієнтів із прогнозованим тяжким ГП. Через 48 год після госпіталізації 39 пацієнтів отримували харчування через назогастральний зонд, а інші 39 - через назоєюнальний. При використанні назогастрального харчування спостерігалася тенденцію до зменшення ризику смерті (4 з 39 пацієнтів у назогастральній групі проти 7 з 39 пацієнтів у групі з назоєюнальним зондом) та загальних інфекційних ускладнень (дев'ять 339 пацієнтів у групі з назогастральним зондом проти 14 з 39 пацієнтів у групі з назоєюнальним). Крім того, кількість побічних ефектів, пов'язаних із харчуванням, була подібною між двома групами, і пацієнти в обох групах не відрізнялися значною мірою 3 точки зору непереносимості їжі. В цілому, результати цього РКД відповідають двом попереднім рандомізованим дослідженням, що порівнювали назогастральне і назоєюнальне дієти у пацієнтів 3 прогнозованим тяжким ГП [86, 87]. Інше РКД 3 назогастрального харчування, що називається MIMOSA (MIld to MOderate acute pancreatitis: early naSogastric tube feeding compared with pAncreatic rest), було першим дослідженням, призначеним для оцінки безпеки, толерантності та ефективності харчування через назогастральний зонд у пацієнтів, крім хворих із тяжким ГП [59]. Загалом 35 пацієнтів без органної недостатності або інфекційних ускладнень під час рандомізації випадковим чином були поділені на групу із харчуванням через назогастральний зонд (у середньому через 22 год після госпіталізації) та групу nil-per-os (голодування). Одна третина цих пацієнтів при госпіталізації мала синдром системної запальної відповіді, а середній показник АРАСНЕ II становив 6 в обох групах. Це дослідження довело, що застосування назогастрального зонда для годування є настільки ж безпечним, як режим nil-per-os у пацієнтів з легкою або середньою тяжкістю захворювання, і приводить до значного зменшення інтенсивності та тривалості болю у животі, потреби в опіатах та ризику виникнення непереносимості при відновленні перорального харчування. 
Крім того, в одному рандомізованому контрольованому дослідженні порівнювали ентеральне харчування через назогастральний зонд із парентеральним харчуванням [21].

3 цими дослідженнями було проведено 3 мета-аналізи $[16,88,89]$. Один із цих мета-аналізів також включав нерандомізовані контрольовані дослідження [88]. Не було суттєвих відмінностей у вислідах в окремих дослідженнях. Відповідно до цих результатів, мета-аналіз [89], що включав 3 рандомізованих дослідження з порівняння назогастрального 3 назоєюнальним харчуванням, не показав різниці в смертності $(\mathrm{RR}=0.69,95 \%$ CI: 0.37 to $1.29, \mathrm{P}=0.25$ ), трахеальній аспірації $(\mathrm{RR}=0.46,95 \% \mathrm{CI}: 0.14$ to $1.53, \mathrm{P}=0.20)$ та досягненні енергетичного балансу (RR $=1.00,95 \%$ CI: 0.92 to 1.09, P = 0.97) між двома групами. Необхідно враховувати наступні обмеження окремих випробувань.

По-перше, вибірки цих досліджень були невеликими, варіюючи від 31 пацієнта [87] до 78 хворих [85]. Тому складно стверджувати, чи були окремі випробування достатньо потужними для виявлення невеликих, але клінічно значимих відмінностей у результатах.

По-друге, критерії включення пацієнтів з ГП коливались між випробуваннями. Були використані різні прогнозувальні системи. Крім того, в одному центрі дослідження [87] пацієнти отримували кілька тижнів нутриційну підтримку в інших центрах до госпіталізації. У результаті характеристики хворих можуть відрізнятися між дослідженнями.

Крім того, ретроспективне дослідження пацієнтів при операціях на підшлунковій залозі показало, що третина назоєюнальних зондів зміщується [90]. В іншому дослідженні [91] було показано, що 40 \% (у 15 з 25 пацієнтів) назогастральних зондів спонтанно мігрували в порожню кишку (за зв'язку Treitz'). У будь-якому випадку обмеження рандомізованих контрольованих досліджень, що порівнюють назогастральне з назоєюнальним харчуванням, полягає в тому, що вони не контролюють місце розташування зонда через кілька днів. У результаті можна поставити під сумнів, чи пацієнти насправді харчувалися через назогастральний або назоєюнальний зонд.

\section{СПИСОК ЛІТЕРАТУРИ}

1. Burden of gastrointestinal disease in the United States: 2012 update / A. F. Peery, E. S. Dellon, J. Lund [et al.] // Gastroenterology. - 2012. - Vol. 143. - P. 1179-1187.

2. Spanier B. Incidence and mortality of acute and chronic pancreatitis in the Netherlands: a nationwide record-linked cohort study for the years 1995-2005 / B. Spanier, M. J. Bruno,
Що стосується легеневих ускладнень, великий мета-аналіз у пацієнтів без панкреатиту [92] порівнював назоєюнальне харчування $з$ назогастральним і показав зменшення кількості пневмоній $(\mathrm{P}=$ 0,004, 15,8 \% проти 22,8 \%) та вентиляційно-асоційованої пневмоній $(\mathrm{P}=0,005,16,9$ \% проти $25 \%)$ при використанні назоєюнального харчування. У цей мета-аналіз було включено 1394 пацієнти з відділення інтенсивної терапії, з яких у 1117 (80 \%) проводилася механічна вентиляція легень. Інші мета-аналізи, однак не виявили суттєвих відмінностей у частоті пневмонії при назогастральному та назоєюнальному годуванні $[93,94]$.

Проте назогастральне харчування виглядає безпечним, якщо добре переноситься. За результатами двох рандомізованих контрольованих досліджень [86, 87], що порівнювали назогастральне та наноєюнальне харчування, прийшли до висновку, що між термінами виписування, хірургічними операціями та смертністю немає різниці між двома шляхами. Послідовний мета-аналіз [95], що включав 157 пацієнтів, показав, що не було суттєвих відмінностей щодо смертності $(\mathrm{RR}=0.69$, 95 \% CI: 0.37 to $1.29, p=0.25)$; трахеальної аспірації (RR=0.46, 95 \% CI: 0.14 to 1.53, $p=0.20$ ), діареї (RR=1.43, $95 \%$ CI: 0.59 to 3.45, $p=0.43$ ); загострення болю (RR=0.94, $95 \%$ CI: 0.32 to $2.70, p=0.90)$; i відповідності енергетичного балансу $(\mathrm{RR}=1.00$, 95 \% CI: 0.92 to $1.09, p=0.97)$ між назогастральним та назоєюнальним годуванням. Таким чином, розміщення кінчика зонда за воротарем шлунка більше не вважається необхідним (клас рекомендацій В) [38, 39, 62]. Це свідчить, що ЕХ доцільніше у клінічній практиці (більше немає потреби в ендоскопічному або рентгенологічному розміщенні харчового зонда). Коли назогастральне годування не переноситься, або коли не потрібна калорійність, рекомендується встановлювати назоєюнальний зонд за зв'язку Treitz'. Велике високоякісне рандомізоване дослідження все ще необхідне, щоб визначити, чи назогастральне або назоєюнальне зондове харчування $є$ оптимальним для початкової стратегії лікування. Цілком можливо, що в найближчому майбутньому новий спосіб розміщення назоєюнальних зондів, використовуючи електромагнітне управління, може покращити методику, пов'язану з їх розміщенням [96-99].

M. G. Dijkgraaf // World J. Gastroenterol, - 2013. - Vol. 19. P. 3018-3026.

3. A conservative and minimally invasive approach to necrotizing pancreatitis improves outcome / H. C. van Santvoort, O. J. Bakker, T. L. Bollen [et al.] // Gastroenterology. - 2011. Vol. 141. - P. 1254-1263. 
4. Organ failure and infection of pancreatic necrosis as determinants of mortality in patients with acute pancreatitis / M. S. Petrov, S. Shanbhag, M. Chakraborty [et al.] // Gastroenterology. 2010. - Vol. 139. - P. 813-820.

5. Acute pancreatitis at the beginning of the 21st century: the state of the art / A. F. Tonsi, M. Bacchion, S. Crippa [et al.] // World J. Gastroenterol. - 2009. - Vol.15. - P. 2945-2959.

6. Muddana V. Current management and novel insights in acute pancreatitis / V. Muddana, D. C. Whitcomb, G. I. Papachristou // Expert Rev. Gastroenterol. Hepatol. - 2009. - Vol. 3. - P. 435-444. 7. Abou-Assi S. Nutrition support during acute pancreatitis / S. Abou-Assi, S. J. O’Keefe // Nutrition. - 2002. - Vol. 18. P. 938-943.

8. Abou-Assi S. Nutrition in acute pancreatitis / S. Abou-Assi, S. J. O’Keefe // J. Clin. Gastroenterol. - 2001. - Vol. 32. - P. 203209.

9. The association of mean glucose level and glucose variability with intensive care unit mortality in patients with severe acute pancreatitis / Y. Y. Zuo, Y. Kang, W. H. Yin [et al.] // J. Crit. Care. - 2012. - Vol. 27. - P.146-152.

10. Pancreatic exocrine insufficiency, diabetes mellitus and serum nutritional markers after acute pancreatitis / M. Vujasinovic, B. Tepes, J. Makuc [et al.] // World J. Gastroenterol. - 2014. Vol. 20. - P. 18432-18438.

11. Staged multidisciplinary step-up management for necrotizing pancreatitis / D. W. da Costa, D. Boerma, H. C. van Santvoort [et al.] // Br. J. Surg. - 2014. - Vol.101. - P. e65-79.

12. Nutrition in the management of necrotizing pancreatitis / S. J. O’Keefe, T. Broderick, M. Turner [et al.] // Clin. Gastroenterol. Hepatol. - 2003. - Vol. 1. - P. 315-323.

13. Ziegler T. R. Parenteral nutrition in the critically ill patient / T. R. Ziegler // N. Engl. J. Med. - 2009. - Vol. 361. - P. 10881097.

14. Trypsin secretion and turnover in patients with acute pancreatitis / S. J. O’Keefe, R. B. Lee, J. Li [et al.] // Am. J. Physiol. Gastrointest. Liver Physiol. - 2005. - Vol. 289. - G181-187.

15. Boreham B. A prospective evaluation of pancreatic exocrine function in patients with acute pancreatitis: correlation with extent of necrosis and pancreatic endocrine insufficiency / B. Boreham, B. J. Ammori // Pancreatology. - 2003. - Vol. 3. - P. 303-308.

16. Petrov M. S. Nasogastric tube feeding in predicted severe acute pancreatitis. A systematic review of the literature to determine safety and tolerance / M. S. Petrov, M. I. Correia, J. A. Windsor // JOP. - 2008. - Vol. 9. - P. 440-448.

17. Meta-analysis of gut barrier dysfunction in patients with acute pancreatitis / L. M. Wu, S. J. Sankaran, L. D. Plank [et al.] // Br. J. Sur. - 2014. - Vol. 101. - P. 1644-1656.

18. Hermsen J. L. Food fight! Parenteral nutrition, enteral stimulation and gut derived mucosal immunity / J. L. Hermsen, Y. Sano, K. A. Kudsk // Langenbeck's Arch. Surg. - 2009. Vol. 394. - P.17-30.

19. Role of the gut barrier in acute pancreatitis / G. Capurso, G. Zerboni, M. Signoretti [et al.] // J. Clin. Gastroenterol. - 2012. - Vol.46, Suppl. - P. 46-51.

20. Bacterial translocation and infected pancreatic necrosis in acute necrotizing pancreatitis derives from small bowel rather than from colon / S. Fritz, T. Hackert, W. Hartwig [et al.] // Am. J. Surg. - 2010. - Vol.200. - P. 111-117.

21. Eckerwall G. E. Early nasogastric feeding in predicted severe acute pancreatitis: A clinical, randomized study / G. E. Eckerwall, J. B. Axelsson, R. G. Andersson // Ann. Surg. - 2006. - Vol. 244. - P. 959-965.

22. Abou-Assi S. Hypocaloric jejunal feeding is better than total parenteral nutrition in acute pancreatitis: results of a randomized comparative study / S. Abou-Assi, K. Craig, S. J. O’Keefe // Am. J. Gastroenterol. - 2002. - Vol. 97. - P. 2255-2262.

23. Total enteral nutrition vs. total parenteral nutrition in patients with severe acute pancreatitis / M. Casas, J. Mora, E. Fort [et al.] // Rev. Esp. Enferm. Dig. - 2007. - Vol. 99. - P. 264-269.

24. A randomised clinical trial to assess the effect of total enteral and total parenteral nutritional support on metabolic, inflammatory and oxidative markers in patients with predicted severe acute pancreatitis (APACHE II > or =6) / R. Gupta, K. Patel, P. C. Calder [et al.] // Pancreatology. - 2003. - Vol. 3. P. 406-413.

25. Enteral nutrition is superior to parenteral nutrition in severe acute pancreatitis: results of a randomized prospective trial / F. Kalfarentzos, J. Kehagias, N. Mead [et al.] // Br. J. Surg. 1997. - Vol. 84. - P. 1665-1669.

26. 2004 MacLean-Mueller prize enteral or parenteral nutrition for severe pancreatitis: a randomized controlled trial and health technology assessment / B. E. Louie, T. Noseworthy, D. Hailey [et al.] // Can. J. Surg. - 2005. - Vol. 48. - P. 298-306.

27. Comparison of the safety of early enteral vs parenteral nutrition in mild acute pancreatitis / S. A. McClave, L. M. Greene, H. L. Snider [et al.] // JPEN. - 1997. - Vol. 21. - P. 14-20.

28. Early nasojejunal feeding in acute pancreatitis is associated with a lower complication rate / A. Olah, G. Pardavi, T. Belagyi [et al.] // Nutrition. - 2002. - Vol. 18. - P.259-262.

29. Petrov M. S. A randomized controlled trial of enteral versus parenteral feeding in patients with predicted severe acute pancreatitis shows a significant reduction in mortality and in infected pancreatic complications with total enteral nutrition / M. S. Petrov, M. V. Kukosh, N. V. Emelyanov // Dig. Surg. 2006. - Vol. 23. - P. 336-344.

30. Total enteral nutrition in prevention of pancreatic necrotic infection in severe acute pancreatitis / X. M. Wu, K. Q. Ji, H. Y. Wang [et al.] // Pancreas. - 2010. - Vol. 39. - P. 248-251. 31. Enteral nutrition in severe acute pancreatitis / R. P. Doley, T. D. Yadav, J. D. Wig [et al.] // JOP. - 2009. - Vol. 10. - P. 157-162. 32. Compared with parenteral nutrition, enteral feeding attenuates the acute phase response and improves disease severity in acute pancreatitis / A. C. Windsor, S. Kanwar, A. G. Li [et al.] // Gut. 1998. - Vol. 42. - P. 431-435.

33. Meta-analysis: total parenteral nutrition versus total enteral nutrition in predicted severe acute pancreatitis / F. Yi, L. Ge, J. Zhao [et al.] // Int. Med. - 2012. - Vol. 51. - P. 523-530.

34. Enteral versus parenteral nutrition for acute pancreatitis / M. Al-Omran, Z. H. Albalawi, M. F. Tashkandi, L. A. Al-Ansary // Cochrane Database Syst. Rev. - 2010. - CD002837.

35. Enteral nutrition and the risk of mortality and infectious complications in patients with severe acute pancreatitis: a metaanalysis of randomized trials / M. S. Petrov, H. C. van Santvoort, M. G. Besselink [et al.] // Arch. Surg. - 2008. - Vol. 143. P. 1111-1117.

36. Working Group IAP/APA Acute Pancreatitis Guidelines IAP/APA evidence-based guidelines for the management of acute pancreatitis / Working Group IAP/APA Acute Pancreatitis Guidelines // Pancreatology. - 2013. - Vol. 13, Suppl. 2. - P. e1-15. 37. American College of Gastroenterology guideline: management of acute pancreatitis / S. Tenner, J. Baillie, J. DeWitt [et al.] // Am. J. Gastroenterol. - 2013. - Vol. 108. - P. 1400-1415. 38. International consensus guidelines for nutrition therapy in pancreatitis / J. M. Mirtallo, A. Forbes, S. A. McClave [et al.] // JPEN. - 2012. - Vol. 36. - P. 284-291.

39. ESPEN Guidelines on Enteral Nutrition: Pancreas / R. Meier, J. Ockenga, M. Pertkiewicz [et al.] // Clin. Nutr. - 2006. - Vol. 25. - P. 275-284. 
40. Comparison of existing clinical scoring systems to predict persistent organ failure in patients with acute pancreatitis / R. Mounzer, C. J. Langmead, B. U. Wu [et al.] // Gastroenterology. - 2012. - Vol. 142. - P.1476-1482.

41. Timing and impact of infections in acute pancreatitis / M. G. Besselink, H. C. van Santvoort, M. A. Boermeester [et al.] // Br. J. Surg. - 2009. - Vol. 96. - P. 267-273.

42. Small study effects in meta-analyses of osteoarthritis trials: meta-epidemiological study / E. Nuesch, S. Trelle, S. Reichenbach [et al.] // BMJ. - 2010. - Vol. 341. - P. c3515.

43. Pleva M. Hyperglycemic events in non-intensive care unit patients receiving parenteral nutrition / M. Pleva, J. M. Mirtallo, S. M. Steinberg // Nutr. Clin. Prac. - 2009. - Vol. 24. - P. 626634.

44. Hyperglycemia during total parenteral nutrition: an important marker of poor outcome and mortality in hospitalized patients / F. J. Pasquel, R. Spiegelman, M. McCauley [et al.] // Diabetes Care. - 2010. - Vol. 33. - P. 739-741.

45. Management of hyperglycemia in hospitalized patients in non-critical care setting: an endocrine society clinical practice guideline / G. E. Umpierrez, R. Hellman, M. T. Korytkowski [et al.] // J. Clin. Endocrinol. Metab. - 2012. - Vol. 97. - P. 16-38.

46. Gosmanov A. R. Management of hyperglycemia during enteral and parenteral nutrition therapy / A. R. Gosmanov, G. E. Umpierrez // Curr. Diab. Rep. - 2013. - Vol. 13. - P. 155-162.

47. Permissive underfeeding or standard enteral feeding in critically Ill adults / Y. M. Arabi, A. S. Aldawood, S. H. Haddad [et al.] // N. Engl. J. Med. - 2015. - Vol. 372. - P. 2398-2408.

48. Bost R. B. Timing of (supplemental) parenteral nutrition in critically ill patients: a systematic review / R. B. Bost, D. H. Tjan, A. R. van Zanten // Ann. Intensive Care. - 2014. - Vol. 4. - P. 31. 49. Early versus late parenteral nutrition in critically ill adults / M. P. Casaer, D. Mesotten, G. Hermans [et al.] // N. Engl. J. Med. - 2011. - Vol. 365. - P. 506-517.

50. Petrov M. S. A systematic review on the timing of artificial nutrition in acute pancreatitis / M. S. Petrov, R. D. Pylypchuk, A. F. Uchugina // Br. J. Nutr. - 2009. - Vol. 101. - P. 787-793.

51. Effects of early enteral nutrition on immune function of severe acute pancreatitis patients / J. K. Sun, X. Mu. W, W. Q. Li [et al.] // World J. Gastroenterol. - 2013. - Vol. 19. - P. 917-922.

52. Early enteral nutrition is superior to delayed enteral nutrition for the prevention of infected necrosis and mortality in acute pancreatitis / U. Wereszczynska-Siemiatkowska, A. SwidnickaSiergiejko, A. Siemiatkowski, A. Dabrowski // Pancreas. - 2013. - Vol. 42. - P. 640-646.

53. Enteral nutrition within 48 hours of admission improves clinical outcomes of acute pancreatitis by reducing complications: a meta-analysis / J. Y. Li, T. Yu, G. C. Chen [et al.] // PLoS One. - 2013. - Vol. 8. - P. e64926.

54. Timing of enteral nutrition in acute pancreatitis: metaanalysis of individuals using a single-arm of randomised trials / O. J. Bakker, S. van Brunschot, A. Farre [et al.] // Pancreatology. - 2014. - Vol. 14. - P. 340-346.

55. Consensus guidelines on severe acute pancreatitis. Italian Association for the Study of the Pancreas (AISP) / R. Pezzilli, A. Zerbi, D. Campra [et al.] // Dig. Liver Dis. - 2015. - Vol. 47. P. 532-543.

56. McClave S. A. Artificial nutrition in pancreatic disease: what lessons have we learned from the literature? / S. A. McClave, C. S. Ritchie // Clin. Nutr. - 2000. - Vol.19. - P. 1-6.

57. A randomized trial of oral refeeding compared with jejunal tube refeeding in acute pancreatitis / S. K. Pandey, V. Ahuja, Y. K. Joshi, M. P. Sharma // Indian J. Gastroenterol. - 2004. Vol. 23. - P. 53-55.
58. Oral refeeding after onset of acute pancreatitis: a review of literature / M. S. Petrov, H. C. van Santvoort, M. G. Besselink [et al.] // Am. J. Gastroenterol. - 2007. - Vol. 102. - P. 2079-2084. 59. Early nasogastric tube feeding versus nil per os in mild to moderate acute pancreatitis: a randomized controlled trial / M. S. Petrov, K. McIlroy, L. Grayson [et al.] // Clin. Nutr. - 2013. - Vol. 32. - P. 697-703.

60. Immediate oral feeding in patients with mild acute pancreatitis is safe and may accelerate recovery - a randomized clinical study / G. E. Eckerwall, B. B. Tingstedt, P. E. Bergenzaun, R. G. Andersson // Clin. Nutr. - 2007. - Vol. 26. - P. 758-763.

61. Optimal timing of oral refeeding in mild acute pancreatitis: results of an open randomized multicenter trial / N. Teich, A. Aghdassi, J. Fischer [et al.] // Pancreas. - 2010. - Vol. 39. P. 088-1092.

62. Clinical practice guideline: management of acute pancreatitis / J. A. Greenberg, J. Hsu, M. Bawazeer [et al.] // Can. J. Surg. 2016. - Vol. 59. - P. 128-140.

63. Clinical trial: oral feeding with a soft diet compared with clear liquid diet as initial meal in mild acute pancreatitis / E. Sathiaraj, S. Murthy, M. J. Mansard [et al.] // Aliment. Pharmacol. Ther. 2008. - Vol. 28. - P. 777-781.

64. Clear liquid diet vs soft diet as the initial meal in patients with mild acute pancreatitis: a randomized interventional trial / N. Rajkumar, V. S. Karthikeyan, S. M. Ali [et al.] // Nutr. Clin. Prac. - 2013. - Vol. 28. - P. 365-370.

65. A full solid diet as the initial meal in mild acute pancreatitis is safe and result in a shorter length of hospitalization: results from a prospective, randomized, controlled, double-blind clinical trial / J. M. Moraes, G. E. Felga, L. A. Chebli [et al.] // J. Clin. Gastroenterol. - 2010. - Vol. 44. - P. 517-522.

66. Spanier B. W. Enteral nutrition and acute pancreatitis: a review / B. W. Spanier, M. J. Bruno, E. M. Mathus-Vliegen // Gastroenterol. Res. Pract. - 2011. - Vol. 2011. - Article ID 857949.

67. Early and/or immediately full caloric diet versus standard refeeding in mild acute pancreatitis: a randomized open-label trial / J. Larino-Noia, B. Lindkvist, J. Iglesias-Garcia [et al.] // Pancreatology. - 2014. - Vol. 14. - P. 167-173.

68. Three initial diets for management of mild acute pancreatitis: a meta-analysis / W. B. Meng, X. Li, Y. M. Li [et al.] // World J. Gastroenterol. - 2011. - Vol. 17. - P. 4235-4241.

69. Early oral refeeding wisdom in patients with mild acute pancreatitis / J. Li, G. J. Xue, Y. L. Liu [et al.] // Pancreas. - 2013. - Vol. 42. - P. 88-91.

70. Early oral refeeding based on hunger in moderate and severe acute pancreatitis: a prospective controlled, randomized clinical trial / X. L. Zhao, S. F. Zhu, G. J. Xue [et al.] // Nutrition. - 2015. - Vol. 31. - P. 171-175.

71. McClave S. A. The physiologic response and associated clinical benefits from provision of early enteral nutrition / S. A. McClave, D. K. Heyland // Nutr. Clin. Pract. - 2009. Vol. 24. - P. 305-315.

72. When to initialize enteral nutrition in patients with severe acute pancreatitis? A retrospective review in a single institution experience (2003-2013) / X. M. Wu, Y. W. Liao, H. Y. Wang [et al.] // Pancreas. - 2015. - Vol. 44. - P. 507-511.

73. Enteral feeding patients with gastric outlet obstruction / S. O’Keefe, S. Rolniak, A. Raina, Graham [et al.] // Nutr. Clin. Pract. - 2012. - Vol. 27. - P. 76-81.

74. ESPEN guidelines on nutrition in acute pancreatitis. European Society of Parenteral and Enteral Nutrition / R. Meier, C. Beglinger, P. Layer [et al.] // Clin. Nutr. - 2002. - Vol. 21. P.173-183. 
75. Early versus on-demand nasoenteric tube feeding in acute pancreatitis / O. J. Bakker, S. van Brunschot, H. C. van Santvoort [et al.] // N. Engl. J. Med. - 2014. - Vol. 371. - P. 1983-1993.

76. Nasoenteric tube complications / S. Prabhakaran, V. A. Doraiswamy, V. Nagaraja [et al.] // Scand. J. Surg. - 2012. Vol. 101. - P. 147-155.

77. Nutrition support in the critical care setting: current practice in Canadian ICUs-opportunities for improvement? / D. K. Heyland, D. Schroter-Noppe, J. W. Drover [et al.] // JPEN. - 2003. Vol. 27. - P. 74-83.

78. Low caloric intake is associated with nosocomial bloodstream infections in patients in the medical intensive care unit / L. Rubinson, G. B. Diette, X. Song [et al.] // Crit. Care Med. 2004. - Vol. 32. - P.350-357.

79. Dvir D. Computerized energy balance and complications in critically ill patients: an observational study / D. Dvir, J. Cohen, P. Singer // Clini. Nutr. - 2006. - Vol. 25. - P. 37-44.

80. Negative impact of hypocaloric feeding and energy balance on clinical outcome in ICU patients / S. Villet, R. L. Chiolero, M. D. Bollmann [et al.] // Clin. Nutr. - 2005. - Vol. 24. - P. 502-509. 81. The relationship between nutritional intake and clinical outcomes in critically ill patients: results of an international multicenter observational study / C. Alberda, L. Gramlich, N. Jones [et al.] // Intensive Care Med. - 2009. - Vol. 35. - P. 1728-1737. 82. O’Keefe S. J. Physiological response of the human pancreas to enteral and parenteral feeding / S. J. O’Keefe // Curr. Opin. Clin. Nutr. Metab. Care. - 2006. - Vol. 9. - P.622-628.

83. Trypsin and splanchnic protein turnover during feeding and fasting in human subjects / S. J. O’Keefe, R. B. Lee, J. Li [et al.] // Am. J. Physiol. Gastrointest. Liver Physiol. - 2006. - Vol. 290. P. G213-221.

84. Enteral feeding without pancreatic stimulation / N. Kaushik, M. Pietraszewski, J. J. Holst, S. J. O’Keefe // Pancreas. - 2005. Vol. 31. - P. 353-359.

85. Evaluation of early enteral feeding through nasogastric and nasojejunal tube in severe acute pancreatitis: a noninferiority randomized controlled trial / N. Singh, B. Sharma, M. Sharma [et al.] // Pancreas. - 2012. - Vol. 41. - P. 153-159.

86. A randomized study of early nasogastric versus nasojejunal feeding in severe acute pancreatitis / F. C. Eatock, P. Chong, N. Menezes [et al.] // Am. J. Gastroenterol. - 2005. - Vol. 100. P. 432-439.

87. Early enteral nutrition in severe acute pancreatitis: a prospective randomized controlled trial comparing nasojejunal and nasogastric routes / A. Kumar, N. Singh, S. Prakash [et al.] //
J. Clin. Gastroenterol. - 2006. - Vol. 40. - P. 431-434.

88. Nasogastric nutrition is efficacious in severe acute pancreatitis: a systematic review and meta-analysis / D. M. Nally, E. G. Kelly, M. Clarke, P. Ridgway // Br. J. Nut. - 2014. - Vol. 112. - P. 17691778.

89. Nasogastric or nasojejunal feeding in predicted severe acute pancreatitis: a meta-analysis / Y. S. Chang, H. Q. Fu, Y. M. Xiao, J. C .Liu // Crit. Care. - 2013. - Vol. 17. - P. R118.

90. Efficacy and complications of nasojejunal, jejunostomy and parenteral feeding after pancreaticoduodenectomy / A. Gerritsen, M. G. Besselink, K. P. Cieslak [et al.] // J. Gastrointest. Surg. 2012. - Vol. 16. - P. 1144-1151.

91. Nasogastric or nasointestinal feeding in severe acute pancreatitis / M. Piciucchi, E. Merola, M. Marignani [et al.] // World J. Gastroenterol. - 2010. - Vol. 16. - P. 3692-3696.

92. Small bowel feeding and risk of pneumonia in adult critically ill patients: a systematic review and meta-analysis of randomized trials / W. Alhazzani, A. Almasoud, R. Jaeschke [et al.] // Crit. Care. - 2013. - Vol.17. - P. R127.

93. Marik P. E. Gastric versus post-pyloric feeding: a systematic review / P. E. Marik, G. P. Zaloga // Crit. Care. - 2003. - Vol. 7. - P. R46-51.

94. Ho K. M. A comparison of early gastric and post-pyloric feeding in critically ill patients: a meta-analysis / K. M. Ho, G. J. Dobb, S. A. Webb // Intensive Care Med. - 2006. - Vol. 32. - P. 639-649.

95. Nasogastric or nasojejunal feeding in predicted severe acute pancreatitis: a meta-analysis / Y. S. Chang, H. Q. Fu, Y. M. Xiao, J. C. Liu // Crit. Care. - 2013. - Vol. 17. - P. R118.

96. Endoscopic versus bedside electromagnetic-guided placement of nasoenteral feeding tubes in surgical patients / A. Gerritsen, T. de Rooij, M. J. van der Poel [et al.] // J. Gastrointest. Sur. 2014. - Vol. 18. - P.1664-1672.

97. Boyer N. Analysis of an electromagnetic tube placement device versus a self-advancing nasal jejunal device for postpyloric feeding tube placement / N. Boyer, M. S. McCarthy, C. A. Mount // J. Hosp. Med. - 2014. - Vol. 9. - P. 23-28.

98. The application of electromagnetically guided post-pyloric feeding tube placement in critically ill patients / X. Wang, L. Zhang, C. Wu [et al.] // J. Invest. Surg. - 2014. - Vol. 27. P. 21-26.

99. Systematic review on bedside electromagnetic-guided, endoscopic, and fluoroscopic placement of nasoenteral feeding tubes / A. Gerritsen, M. J. van der Poel, T. de Rooij [et al.] // Gastrointest. Endosc. - 2015. - Vol. 81. - P. 836-847.

\section{REFERENCES}

1. Peery, A.F., Dellon, E.S., Lund, J., Crockett, S.D., McGowan, C.E., Bulsiewicz, W.J., ..., Shaheen, N.J. (2012). Burden of gastrointestinal disease in the United States: 2012 update. Gastroenterology, 143 (5), 1179-1187. doi: 10.1053/j. gastro.2012.08.002

2. Spanier, B., Bruno, M.J., \& Dijkgraaf, M.G. (2013). Incidence and mortality of acute and chronic pancreatitis in the Netherlands: a nationwide record-linked cohort study for the years 1995-2005. World J. Gastroenterol., 19 (20), 3018-3026. doi: 10.3748/wjg. v19.i20.3018

3. Van Santvoort, H.C., Bakker, O.J., Bollen, T.L., Besselink, M.G., Ahmed, Ali U., Schrijver, A.M., ..., Dutch Pancreatitis Study Group. (2011). A conservative and minimally invasive approach to necrotizing pancreatitis improves outcome. Gastroenterology, 141 (4), 1254-1263. doi: 10.1053/j.gastro.2011.06.073

4. Petrov, M.S., Shanbhag, S., Chakraborty, M., Phillips, A.R., \& Windsor, J.A. (2010). Organ failure and infection of pancreatic necrosis as determinants of mortality in patients with acute pancreatitis. Gastroenterology, 139 (3), 813-820. doi: 10.1053/j. gastro.2010.06.010

5. Tonsi, A.F., Bacchion, M., Crippa, S., Malleo, G., \& Bassi, C. (2009). Acute pancreatitis at the beginning of the 21st century: the state of the art. World J. Gastroenterol., 15 (24), 2945-2959. doi: 0.3748/wjg.15.2945

6. Muddana, V., Whitcomb, D.C., \& Papachristou, G.I. (2009). Current management and novel insights in acute pancreatitis. Expert Review of Gastroenterology \& Hepatology, 3 (4), 435444. doi: 10.1586/egh.09.27

7. Abou-Assi, S., \& O'Keefe, S.J. (2002). Nutrition support during acute pancreatitis. Nutrition, 18 (11-12), 938-943. 
8. Abou-Assi, S., \& O'Keefe, S.J. (2001). Nutrition in acute pancreatitis. Journal of Clinical Gastroenterology, 32 (3), 203209.

9. Zuo, Y.Y., Kang, Y., Yin, W.H., Wang, B., \& Chen, Y. (2012). The association of mean glucose level and glucose variability with intensive care unit mortality in patients with severe acute pancreatitis. Journal of Critical Care, 27 (2), 146152. doi: 10.1016/j.jcrc.2011.12.004

10. Vujasinovic, M., Tepes, B., Makuc, J., Rudolf, S., Zaletel, J., Vidmar, T., ..., Birsa, B. (2014). Pancreatic exocrine insufficiency, diabetes mellitus and serum nutritional markers after acute pancreatitis. World J. Gastroenterol., 20 (48), 18432-18438. doi: 10.3748/wjg.v20.i48.18432

11. da Costa, D.W., Boerma, D., van Santvoort, H.C., Horvath, K.D., Werner, J., Carter, C.R., ..., Bakker, O.J. (2014). Staged multidisciplinary step-up management for necrotizing pancreatitis. The British Journal of Surgery, 101 (1), e65-79. doi: 10.1002/bjs.9346

12. O'Keefe, S.J., Broderick, T., Turner, M., Stevens S., \& O'Keefe, J.S. (2003). Nutrition in the management of necrotizing pancreatitis. Clinical Gastroenterology and Hepatology, 1 (4), 315-321.

13. Ziegler, T.R. (2009). Parenteral nutrition in the critically ill patient. The New England Journal of Medicine, 361 (11), 10881097. doi: 10.1056/NEJMct0806956

14. O’Keefe, S.J., Lee, R.B., Li, J., Stevens, S., Abou-Assi, S., Zhou, W. (2005). Trypsin secretion and turnover in patients with acute pancreatitis. Am. J. Physiol. Gastrointest. Liver Physiol., 289 (2), G181-G187. doi: 10.1152/ajpgi.00297.2004

15. Boreham, B., \& Ammori, B.J. (2003). A prospective evaluation of pancreatic exocrine function in patients with acute pancreatitis: correlation with extent of necrosis and pancreatic endocrine insufficiency. Pancreatology, 3 (4), 303-308. doi: 10.1159/000071768

16. Petrov, M.S., Correia, M.I., \& Windsor, J.A. (2008). Nasogastric tube feeding in predicted severe acute pancreatitis. A systematic review of the literature to determine safety and tolerance. JOP, 9 (4), 440-448.

17. Wu, L.M., Sankaran, S.J., Plank, L.D., Windsor, J.A., \& Petrov, M.S. (2014). Meta-analysis of gut barrier dysfunction in patients with acute pancreatitis. The British Journal of Surgery, 101 (13), 1644-1656. doi: 10.1002/bjs.9665

18. Hermsen, J.L., Sano, Y., \& Kudsk, K.A. (2009). Food fight! Parenteral nutrition, enteral stimulation and gut derived mucosal immunity. Langenbeck's Archives of Surgery, 394 (1), 17-30. doi: 10.1007/s00423-008-0339-x

19. Capurso, G., Zerboni, G., Signoretti, M., Valente, R., Stigliano, S., Piciucchi, M., ..., Delle Fave, G. (2012). Role of the gut barrier in acute pancreatitis. Journal of Clinical Gastroenterology, 46, S46-51. doi: 10.1097/MCG.0b013e3182652096

20. Fritz, S., Hackert, T., Hartwig, W., Rossmanith, F., Strobel, O., Schneider, L., ..., Werner, J. (2010). Bacterial translocation and infected pancreatic necrosis in acute necrotizing pancreatitis derives from small bowel rather than from colon. American Journal of Surgery, 200 (1), 111-117. doi: 10.1016/j.amjsurg.2009.08.019 21. Eckerwall, G.E., Axelsson, J.B., \& Andersson, R.G. (2006). Early nasogastric feeding in predicted severe acute pancreatitis: A clinical, randomized study. Annals of Surgery, 244 (6), 959-967. doi: 10.1097/01.sla.0000246866.01930.58

22. Abou-Assi, S., Craig, K., O'Keefe, S.J. (2002). Hypocaloric jejunal feeding is better than total parenteral nutrition in acute pancreatitis: results of a randomized comparative study. The American Journal of Gastroenterology, 97 (9), 2255-2262. doi: 10.1111/j.1572-0241.2002.05979.x
23. Casas, M., Mora, J., Fort, E., Aracil, C., Busquets, D., Galter, S., ..., Farré, A. (2007). Total enteral nutrition vs. total parenteral nutrition in patients with severe acute pancreatitis. Revista Espanola de Enfermedades Digestivas, 99 (5), 264-269.

24. Gupta, R., Patel, K., Calder, P.C., Yaqoob, P., Primrose, J.N., Johnson, C.D. (2003). A randomised clinical trial to assess the effect of total enteral and total parenteral nutritional support on metabolic, inflammatory and oxidative markers in patients with predicted severe acute pancreatitis (APACHE II > or $=6$ ). Pancreatology, 3 (5), 406-413. doi: 10.1159/000073657

25. Kalfarentzos, F., Kehagias, J., Mead, N., Kokkinis, K., \& Gogos, C.A. (1997). Enteral nutrition is superior to parenteral nutrition in severe acute pancreatitis: results of a randomized prospective trial. The British Journal of Surgery, 84 (12), 1665-1669.

26. Louie, B.E., Noseworthy, T., Hailey, D., Gramlich, L.M., Jacobs, P., Warnock, G.L. (2005). 2004 MacLean-Mueller prize enteral or parenteral nutrition for severe pancreatitis: a randomized controlled trial and health technology assessment. Canadian Journal of Surgery, 48 (4), 298-306.

27. McClave, S.A., Greene, L.M., Snider, H.L, Makk, L.J., Cheadle, W.G., Owens, N.A., ..., Goldsmith, L.J. (1997) Comparison of the safety of early enteral vs parenteral nutrition in mild acute pancreatitis. JPEN. Journal of Parenteral and Enteral Nutrition, 21 (1), 14-20. doi: 10.1177/014860719702100114 28. Olah, A., Pardavi, G., Belagyi, T., Nagy, A., Issekutz, A., \& Mohamed, G.E. (2002). Early nasojejunal feeding in acute pancreatitis is associated with a lower complication rate. Nutrition, 18 (3), 259-262.

29. Petrov, M.S., Kukosh, M.V., \& Emelyanov, N.V. (2006). A randomized controlled trial of enteral versus parenteral feeding in patients with predicted severe acute pancreatitis shows a significant reduction in mortality and in infected pancreatic complications with total enteral nutrition. Digestive Surgery, 23 (5-6), 336-344. doi: 0.1159/000097949

30. Wu, X.M., Ji, K.Q., Wang, H.Y., Li, G.F., Zang, B., \& Chen, W.M. (2010). Total enteral nutrition in prevention of pancreatic necrotic infection in severe acute pancreatitis. Pancreas, 39 (2), 248-251. doi: 10.1097/MPA.0b013e3181bd6370

31. Doley, R.P., Yadav, T.D., Wig, J.D., Kochhar, R., Singh, G., Bharathy, K.G., ..., Vaishnavi, C. (2009). Enteral nutrition in severe acute pancreatitis. JOP: Journal of the Pancreas, 10 (2), 157-162.

32. Windsor, A.C., Kanwar, S., Li, A.G., Barnes, E., Guthrie, J.A., Spark, J.I., ..., Reynolds, J.V. (1998). Compared with parenteral nutrition, enteral feeding attenuates the acute phase response and improves disease severity in acute pancreatitis. Gut, 42 (3), 431-435. 33. Yi, F., Ge, L., Zhao, J., Lei, Y., Zhou, F., Chen, Z., Xia, B. (2012). Meta-analysis: total parenteral nutrition versus total enteral nutrition in predicted severe acute pancreatitis. Internal Medicine (Tokyo, Japan), 51 (6), 523-530.

34. Al-Omran, M., Albalawi, Z.H., Tashkandi, M.F., \& AlAnsary, L.A. (2010). Enteral versus parenteral nutrition for acute pancreatitis. The Cochrane Database of Systematic Reviews, CD002837. doi: 10.1002/14651858.CD002837.pub2

35. Petrov, M.S., van Santvoort, H.C., Besselink, M.G., van der Heijden, G.J., Windsor, J.A., Gooszen, H.G. (2008). Enteral nutrition and the risk of mortality and infectious complications in patients with severe acute pancreatitis: a meta-analysis of randomized trials. Archives of Surgery, 143 (11), 1111-1117. doi: 10.1001/archsurg.143.11.1111

36. Working Group IAP/APA Acute Pancreatitis Guidelines. (2013). IAP/APA evidence-based guidelines for the management of acute pancreatitis. Pancreatology, 13 (4 Suppl. 2), e1-15. doi: 10.1016/j.pan.2013.07.063

37. Tenner, S., Baillie, J., DeWitt, J., Vege, S.S., ..., American 
College of Gastroenterology. (2013). American College of Gastroenterology guideline: management of acute pancreatitis. The American Journal of Gastroenterology, 108 (9), 1400-1415, 1416. doi: 10.1038/ajg.2013.218

38. Mirtallo, J.M., Forbes, A., McClave, S.A., Jensen, G.L., Waitzberg, D.L., Davies A.R., ..., International Consensus Guideline Committee Pancreatitis Task Force. (2012). International consensus guidelines for nutrition therapy in pancreatitis. JPEN. Journal of Parenteral and Enteral Nutrition, 36 (3), 284-291. doi: 10.1177/0148607112440823

39. Meier, R., Ockenga, J., Pertkiewicz, M., Pap, A, Milinic, N., Macfie, J., ..., ESPEN (European Society for Parenteral and Enteral Nutrition). (2006). ESPEN Guidelines on Enteral Nutrition: Pancreas. Clinical Nutrition, 25 (2), 275-284. doi: 10.1016/j.clnu.2006.01.019

40. Mounzer, R., Langmead, C.J., Wu, B.U., Evans, A.C., Bishehsari, F., Muddana, V., ..., Papachristou, G.I. (2012). Comparison of existing clinical scoring systems to predict persistent organ failure in patients with acute pancreatitis. Gastroenterology, 142 (7), 1476-1482. doi: 10.1053/j. gastro.2012.03.005

41. Besselink, M.G., van Santvoort, H.C., Boermeester, M.A., Nieuwenhuijs, V.B., van Goor, H., Dejong, C.H., ..., Dutch Acute Pancreatitis Study Group. (2009). Timing and impact of infections in acute pancreatitis. The British Journal of Surgery, 96 (3), 267-273. doi: 10.1002/bjs.6447

42. Nuesch, E., Trelle, S., Reichenbach, S., Rutjes, A., Tschannen, B., Altman, D., ..., Juni, P. (2010). Small study effects in meta-analyses of osteoarthritis trials: meta-epidemiological study. BMJ, 341, c3515. doi: 10.1136/bmj.c3515

43. Pleva, M., Mirtallo, J.M., \& Steinberg, S.M. (2009). Hyperglycemic events in non-intensive care unit patients receiving parenteral nutrition. Nutrition in Clinical Practice: Official Publication of the American Society for Parenteral and Enteral Nutrition, 24 (5), 626-634. doi: 10.1177/0884533609339069

44. Pasquel, F.J., Spiegelman, R., McCauley, M., Smiley, D., Umpierrez, D., Johnson, R., ..., Umpierrez, G.E. (2010). Hyperglycemia during total parenteral nutrition: an important marker of poor outcome and mortality in hospitalized patients. Diabetes Care, 33 (4), 739-741. doi: 10.2337/dc09-1748

45. Umpierrez, G.E., Hellman, R., Korytkowski, M.T., Maynard, G.A., Montori, V.M., Seley, J.J., ..., Endocrine Society. (2012). Management of hyperglycemia in hospitalized patients in non-critical care setting: an endocrine society clinical practice guideline. The Journal of Clinical Endocrinology and Metabolism, 97 (1), 16-38. doi: 10.1210/jc.2011-2098

46. Gosmanov, A.R., \& Umpierrez, G.E. (2013). Management of hyperglycemia during enteral and parenteral nutrition therapy. Current Diabetes Reports, 13 (1), 155-162. doi: 10.1007/s11892012-0335-y

47. Arabi, Y.M., Aldawood, A.S., Haddad, S.H., Tamim, H.M., Haddad, S.H., Jones, G., ..., PermiT trial group. (2015). Permissive Underfeeding or Standard Enteral Feeding in Critically Ill Adults. The New England Journal of Medicine, 372 (25), 2398-2408. doi: 10.1164/rccm.201605-1012OC

48. Bost, R.B., Tjan, D.H., \& van Zanten, A.R. (2014). Timing of (supplemental) parenteral nutrition in critically ill patients: a systematic review. Annals of Intensive Care, 4, 31. doi: 10.1186/ s13613-014-0031-y

49. Casaer, M.P., Mesotten, D., Hermans, G., Wouters, P.J., Schetz, M., Meyfroidt, G., ..., Van den Berghe, G. (2011). Early versus late parenteral nutrition in critically ill adults. The New England Journal of Medicine, 365 (6), 506-517. doi: 10.1056/ NEJMoa1102662
50. Petrov, M.S., Pylypchuk, R.D., \& Uchugina, A.F. (2009). A systematic review on the timing of artificial nutrition in acute pancreatitis. The British Journal of Nutrition; 101 (6), 787-793. doi: 10.1017/S0007114508123443

51. Sun, J.K., Mu, X.W., Li, W.Q., Tong, Z.H., Li, J., \& Zheng, S.Y. (2013). Effects of early enteral nutrition on immune function of severe acute pancreatitis patients. World $J$. Gastroenterol., 19 (6), 917-922. doi: 10.3748/wjg.v19.i6.917

52. Wereszczynska-Siemiatkowska, U., Swidnicka-Siergiejko, A., Siemiatkowski, A., \& Dabrowski, A. (2013). Early enteral nutrition is superior to delayed enteral nutrition for the prevention of infected necrosis and mortality in acute pancreatitis. Pancreas, 42 (4) 640-646. doi: 10.1097/MPA.0b013e318271bb61

53. Li, J.Y., Yu, T., Chen, G.C., Yuan, Y.H., Zhong, W., Zhao, L.N., \& Chen, Q.K. (2013) Enteral nutrition within 48 hours of admission improves clinical outcomes of acute pancreatitis by reducing complications: a meta-analysis. PLoS One, 8 (6), e64926. doi: 10.1371/journal.pone.0064926

54. Bakker, O.J., van Brunschot, S., Farre, A., Johnson, C.D., Kalfarentzos, F., Louie, B.E., ..., Gooszen, H.G. (2014). Timing of enteral nutrition in acute pancreatitis: meta-analysis of individuals using a single-arm of randomised trials. Pancreatology, 14 (5), 340-346. doi: 10.1016/j.pan.2014.07.008

55. Pezzilli, R., Zerbi, A., Campra, D., Capurso, G., Golfieri, R., Arcidiacono, P.G., ... Balzano, G. (2015). Consensus guidelines on severe acute pancreatitis. Digestive and Liver Disease, 47 (7), 532-543. doi: 10.1016/j.dld.2015.03.022

56. McClave, S.A., \& Ritchie, C.S. (2000). Artificial nutrition in pancreatic disease: what lessons have we learned from the literature? Clinical Nutrition, 19 (1), 1-6. doi: 0.1054/ clnu.1999.0071

57. Pandey, S.K., Ahuja, V., Joshi, Y.K., \& Sharma, M.P. (2004). A randomized trial of oral refeeding compared with jejunal tube refeeding in acute pancreatitis. Indian Journal of Gastroenterology, 23 (2), 53-55.

58. Petrov, M.S., van Santvoort, H.C., Besselink, M.G., Cirkel, G.A., Brink, M.A., \& Gooszen, H.G. (2007). Oral refeeding after onset of acute pancreatitis: a review of literature. The American Journal of Gastroenterology, 102 (9), 2079-2084. doi: 10.1111/j.1572-0241.2007.01357.x

59. Petrov, M.S., McIlroy, K., Grayson, L., Phillips, A.R., \& Windsor, J.A. (2013). Early nasogastric tube feeding versus nil per os in mild to moderate acute pancreatitis: a randomized controlled trial. Clinical Nutrition, 32 (5), 697-703. doi: 10.1016/j. clnu.2012.12.011

60. Eckerwall, G.E., Tingstedt, B.B., Bergenzaun, P.E., \& Andersson, R.G. (2007). Immediate oral feeding in patients with mild acute pancreatitis is safe and may accelerate recovery - a randomized clinical study. Clinical Nutrition, 26 (6), 758-763. doi: 10.1016/j.clnu.2007.04.007

61. Teich, N., Aghdassi, A., Fischer, J., Walz, B., Caca, K., Wallochny, T., ..., Schiefke, I. (2010). Optimal timing of oral refeeding in mild acute pancreatitis: results of an open randomized multicenter trial. Pancreas, 39 (7), 1088-1092. doi: 10.1097/ MPA.0b013e3181d3ce05

62. Greenberg, J.A., Hsu, J., Bawazeer, M., Marshall, J., Friedrich, J.O., Nathens, A., ..., McLeod, R.S. (2016). Clinical practice guideline: management of acute pancreatitis. Canadian Journal of Surgery, 59 (2) 128-140. doi: 10.1503/cjs.015015 63. Sathiaraj, E., Murthy, S., Mansard, M.J., Rao, G.V., Mahukar, S., \& Reddy, D.N. (2008) Clinical trial: oral feeding with a soft diet compared with clear liquid diet as initial meal in mild acute pancreatitis. Alimentary Pharmacology \& Therapeutics, 28 (6), 777-781. 
64. Rajkumar, N., Karthikeyan, V.S., Ali, S.M., Sistla, S.C., \& Kate, V. (2013). Clear liquid diet vs soft diet as the initial meal in patients with mild acute pancreatitis: a randomized interventional trial. Nutrition in Clinical Practice, 28 (3), 365-370. doi: 10.1177/0884533612466112

65. Moraes, J.M., Felga, G.E., Chebli, L.A., Franco, M.B., Gomes, C.A., Gaburri, P.D., ..., Chebli, J.M. (2010). A full solid diet as the initial meal in mild acute pancreatitis is safe and result in a shorter length of hospitalization: results from a prospective, randomized, controlled, double-blind clinical trial. Journal of Clinical Gastroenterology, 44 (7), 517-522. doi: 10.1097/ MCG.0b013e3181c986b3

66. Spanier, B.W., Bruno, M.J., \& Mathus-Vliegen, E.M. (2011). Enteral nutrition and acute pancreatitis: a review. World $J$. Gastroenterol., 20 (43), 16123-16131. doi: 10.3748/wjg.v20. i43.16123

67. Larino-Noia, J., Lindkvist, B., Iglesias-Garcia, J., SeijoRios, S., Iglesias-Canle, J., \& Dominguez-Munoz, J.E. (2014). Early and/or immediately full caloric diet versus standard refeeding in mild acute pancreatitis: a randomized open-label trial. Pancreatology, 14 (3), 167-173. doi: 10.1016/j.pan.2014.02.008 68. Meng, W.B., Li, X., Li, Y.M., Zhou, W.C., Zhu, X.L. (2011). Three initial diets for management of mild acute pancreatitis: a meta-analysis. World Journal of Gastroenterology, 17 (37), 42354241. doi: 10.3748/wjg.v17.i37.4235

69. Li, J., Xue, G.J., Liu, Y.L. Zhao, X.L., Wan, M.H., Chen, G.Y., ..., Tang, W.F. (2013) Early oral refeeding wisdom in patients with mild acute pancreatitis. Pancreas, 42(1), 88-91. doi: 10.1097/MPA.0b013e3182575fb5

70. Zhao, X.L., Zhu, S.F., Xue, G.J., Li, J., Liu, Y.L., Wan, M.H., ... Tang, W.F. (2015). Early oral refeeding based on hunger in moderate and severe acute pancreatitis: a prospective controlled, randomized clinical trial. Nutrition, 31 (1), 171-175. doi: 10.1016/j.nut.2014.07.002

71. McClave, S.A., \& Heyland, D.K. (2009). The physiologic response and associated clinical benefits from provision of early enteral nutrition. Nutrition in Clinical Practice, 24 (3), 305-315. doi: 10.1177/0884533609335176

72. Wu, X.M., Liao, Y.W., Wang, H.Y., Ji, K.Q., Li, G.F., \& Zang, B. (2015). When to initialize enteral nutrition in patients with severe acute pancreatitis? A retrospective review in a single institution experience (2003-2013). Pancreas, 44 (3), 507-511. doi: 10.1097/MPA.0000000000000293

73. O’Keefe, S., Rolniak, S., Raina, A., Graham, T., Hegazi, R., \& Centa-Wagner, P. (2012). Enteral feeding patients with gastric outlet obstruction. Nutrition in Clinical Practice, 27 (1), 76-81. doi: 10.1177/0884533611432935

74. Meier, R., Beglinger, C., Layer, P., Gullo, L., Keim, V., Laugier, R., Friess, H, ..., ESPEN Consensus Group. ESPEN guidelines on nutrition in acute pancreatitis. European Society of Parenteral and Enteral Nutrition. Clinical Nutrition (Edinburgh, Scotland), 21 (2), 173-183. doi: 10.1054/clnu.2002.0543

75. Bakker, O.J., van Brunschot, S., van Santvoort, H.C., Besselink, M., Bollen, T.L., Boermeester, M., ..., Group the Dutch Pancreatitis Study. (2014) Early versus on-demand nasoenteric tube feeding in acute pancreatitis. The New England Journal of Medicine, 371 (21), 1983-1993. doi: 10.1056/NEJMoa1404393

76. Prabhakaran, S., Doraiswamy, V.A., Nagaraja, V., Cipolla, J., Ofurum, U., Evans, D.C., ..., Stawicki, S.P. (2012). Nasoenteric tube complications. Scandinavian Journal of Surgery, 101 (3), 147-155. doi: 10.1177/145749691210100302

77. Heyland, D.K., Schroter-Noppe, D., Drover, J.W., Jain, M., Keefe, L., Dhaliwal, R., Day, A. (2003). Nutrition support in the critical care setting: current practice in Canadian ICUs- opportunities for improvement? JPEN. Journal of Parenteral and Enteral Nutrition, 27 (1), 74-83. doi: 10.1177/ 014860710302700174

78. Rubinson, L., Diette, G.B., Song, X., Brower, R.G., \& Krishnan, J.A. (2004). Low caloric intake is associated with nosocomial bloodstream infections in patients in the medical intensive care unit. Critical Care Medicine, 32 (2), 350-357. doi: 10.1097/01.CCM.0000089641.06306.68

79. Dvir, D., Cohen, J., \& Singer, P. (2006). Computerized energy balance and complications in critically ill patients: an observational study. Clinical Nutrition, 25 (1), 37-44. doi: 10.1016/j.clnu.2005.10.010

80. Villet, S., Chiolero, R.L., Bollmann, M.D., Revelly, J.P., Cayeux, R. N. M.C., Delarue, J., \& Berger, M.M. (2005). Negative impact of hypocaloric feeding and energy balance on clinical outcome in ICU patients. Clinical Nutrition, 24 (4), 502509. doi: 10.1016/j.clnu.2005.03.006

81. Alberda, C., Gramlich, L., Jones, N., Jeejeebhoy, K., Day, A.G., Dhaliwal, R., \& Heyland, D.K. (2009). The relationship between nutritional intake and clinical outcomes in critically ill patients: results of an international multicenter observational study. Intensive Care Medicine, 35 (10), 17281737. doi: 10.1007/s00134-009-1567-4

82. O'Keefe, S.J. (2006). Physiological response of the human pancreas to enteral and parenteral feeding. Current Opinion in Clinical Nutrition and Metabolic Care, 9 (5), 622-628. doi: 10.1097/01.mco.0000241675.63041.ca

83. O'Keefe, S.J., Lee, R.B., Li, J., Zhou, W., Stoll, B., \& Dang, Q. (2006). Trypsin and splanchnic protein turnover during feeding and fasting in human subjects. American Journal of Physiology. Gastrointestinal and Liver Physiology, 290 (2), G213-221. doi: 10.1152/ajpgi.00170.2005

84. Kaushik, N., Pietraszewski, M., Holst, J.J., \& O'Keefe, S.J. (2005). Enteral feeding without pancreatic stimulation. Pancreas, 31 (4), 353-359.

85. Singh, N., Sharma, B., Sharma, M., Sachdev, V., Bhardwaj, P., Mani, K., ..., Saraya, A. (2012). Evaluation of early enteral feeding through nasogastric and nasojejunal tube in severe acute pancreatitis: a noninferiority randomized controlled trial. Pancreas, 41 (1), 153-159. doi: 10.1097/MPA.0b013e318221c4a8 86. Eatock, F.C., Chong, P., Menezes, N., Murray, L, McKay, C.J., Carter, C.R., \& Imrie, C.W. (2005). A randomized study of early nasogastric versus nasojejunal feeding in severe acute pancreatitis. The American Journal of Gastroenterology, 100 (2), 432-439. doi: 10.1111/j.1572-0241.2005.40587.x

87. Kumar, A., Singh, N., Prakash, S., Saraya, A., \& Joshi, Y.K. (2006). Early enteral nutrition in severe acute pancreatitis: a prospective randomized controlled trial comparing nasojejunal and nasogastric routes. Journal of Clinical Gastroenterology, 40 (5), 431-434.

88. Nally, D.M., Kelly, E.G., Clarke, M., \& Ridgway, P. (2014). Nasogastric nutrition is efficacious in severe acute pancreatitis: a systematic review and meta-analysis. The British Journal of Nutrition, 112 (11), 1769-1778. doi: 10.1017/S0007114514002566 89. Chang, Y.S., Fu, H.Q., Xiao, Y.M., \& Liu, J.C. (2013). Nasogastric or nasojejunal feeding in predicted severe acute pancreatitis: a meta-analysis. Critical Care, 17 (3), R118. doi: 10.1186/cc12790

90. Gerritsen, A., Besselink, M.G., Cieslak, K.P., Vriens, M.R., Steenhagen, E., van Hillegersberg, R., ... Molenaar, I.Q. (2012). Efficacy and complications of nasojejunal, jejunostomy and parenteral feeding after pancreaticoduodenectomy. Journal of Gastrointestinal Surgery, 16 (6), 1144-1151. doi: 10.1007/ s11605-012-1887-5 
91. Piciucchi, M., Merola, E., Marignani, M., Signoretti, M., Valente, R., Cocomello, L., ... Delle Fave, G. (2010). Nasogastric or nasointestinal feeding in severe acute pancreatitis. World Journal of Gastroenterology, 16 (29), 3692-3696. doi: 10.3748/ wjg.v16.i29.3692

92. Alhazzani, W., Almasoud, A., Jaeschke, R., Lo, B.W., Sindi, A., Altayyar, S., \& Fox-Robichaud, A.E. (2013). Small bowel feeding and risk of pneumonia in adult critically ill patients: a systematic review and meta-analysis of randomized trials. Critical Care, 17 (4), R127. doi: 10.1186/cc12806

93. Marik, P.E., \& Zaloga, G.P. (2003). Gastric versus postpyloric feeding: a systematic review. Critical Care, 7 (3), R4651. doi: 10.1186/cc2190

94. Ho, K.M., Dobb, G.J., \& Webb, S.A. (2006). A comparison of early gastric and post-pyloric feeding in critically ill patients: a meta-analysis. Intensive Care Medicine, 32 (5), 639-649. doi: 10.1007/s00134-006-0128-3

95. Chang, Y.S., Fu, H.Q., Xiao, Y.M., \& Liu, J.C. (2013). Nasogastric or nasojejunal feeding in predicted severe acute pancreatitis: a meta-analysis. Critical Care (London, England), 17 (3), R118. doi: 10.1186/cc12790
96. Gerritsen, A., de Rooij, T., van der Poel, M.J., Dijkgraaf, M.G., Bemelman, W.A., Busch, O.R., ... Mathus-Vliegen, E.M. (2014). Endoscopic versus bedside electromagnetic-guided placement of nasoenteral feeding tubes in surgical patients. Journal of Gastrointestinal Surgery, 18 (9), 1664-1672. doi: 10.1007/ s11605-014-2582-2585

97. Boyer, N., McCarthy, M.S., \& Mount, C.A. (2014). Analysis of an electromagnetic tube placement device versus a selfadvancing nasal jejunal device for postpyloric feeding tube placement. Journal of Hospital Medicine, 9 (1), 23-28. doi: 10.1002/jhm.2122

98. Wang, X., Zhang, L., Wu, C., Li, N., \& Li, J. (2014). The application of electromagnetically guided post-pyloric feeding tube placement in critically ill patients. Journal of Investigative Surgery, 27 (1), 21-26. doi: 10.3109/08941939.2013.826310

99. Gerritsen, A., van der Poel, M.J., de Rooij, T., Molenaar, I.Q., Bergman, J.J., Busch, O.R., ... Besselink, M.G. (2015). Systematic review on bedside electromagnetic-guided, endoscopic, and fluoroscopic placement of nasoenteral feeding tubes. Gastrointestinal Endoscopy, 81 (4), 836-847. doi: 10.1016/j. gie.2014.10.040

Отримано 19.06.2018

Електронна адреса для листування: chuklin_serge@hotmail.com

S. M. CHOOKLIN, S. S. CHUKLIN, G. V. SHERSHEN, P. M. POPYK

Lviv Regional Clinical Hospital

\title{
FEATURES OF NUTRITIONAL SUPPORT IN PATIENTS WITH ACUTE PANCREATITIS (LITERATURE REVIEW)
}

Nutrition is an essential part of the treatment of patients with acute pancreatitis. Obviously, in mild and moderately cases, there is no need to use artificial nutrition methods, on the contrary it is recommended to start oral intake of food. However, what food and the timing of its start are still being discussed. However, if the patient's condition is severe to begin enteral nutrition is recommended, which reduces the risk of infection, the length of stay in the hospital, mortality. Parenteral nutrition is prescribed when the enteral is not possible. However, it remains debatable what kind of nutrition to use better, more effective way of use, and also the correct algorithm of actions at the same time. A review of the literature is devoted to all these issues. Summarizing, it can be argued about the need for more studies on nutrition in patients with acute pancreatitis.

Key words: acute pancreatitis; treatment; nutrition.

\section{ОСОБЕННОСТИ ПИЩЕВОЙ ПОДДЕРЖКИ У БОЛЬНЫХ ОСТРЫМ ПАНКРЕАТИТОМ (ОБЗОР ЛИТЕРАТУРЫ)}

\begin{abstract}
Питание является существенной частью лечения больных острым панкреатитом. Очевидно, в легких и средней тяжести случаях отпадает необходимость применять искусственные методы питания, наоборот, рекомендуется начать пероральный прием пищи. Однако, какое питание и сроки его начала еще обсуждаются. Если же состояние пациента тяжелое, целесообразно начать энтеральное питание, которое уменьшает риск присоединения инфекции, продолжительность пребывания в стационаре, смертность. Парентеральное питание назначается, когда энтеральное невозможно. Однако остаются дискуссионными, какой вид питания применять лучше, более эффективный путь введения, а также правильный алгоритм действий при этом. Рассмотрению всех этих вопросов посвящен данный обзор литературы. Подытоживая, можно утверждать о необходимости проведения большего количества исследований по питанию у больных острым панкреатитом.
\end{abstract}

Ключевые слова: острый панкреатит; лечение; пищевая поддержка. 